بررسى بتانسيل باكترى ويبريو فيشرى (Vibrio fischeri) براى پايش آلودگى نفتى در محيطهاى آبى

مرضيه ميرجانى'، محسن سليمانى '"* و وحيد سالارى'

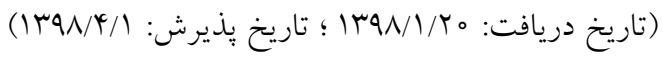

جكيده

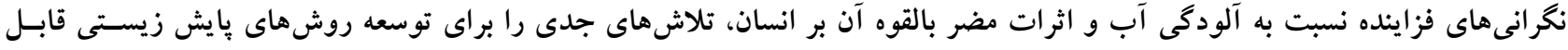

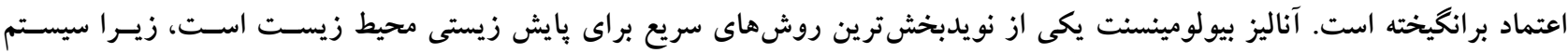

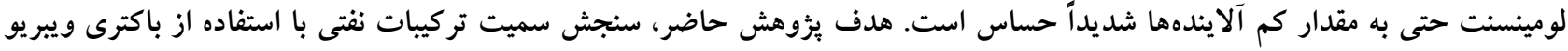

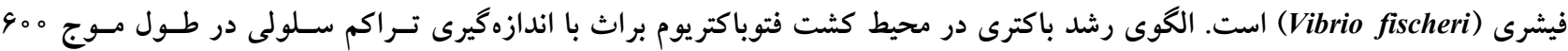

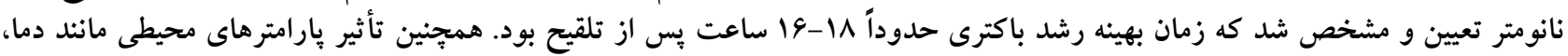

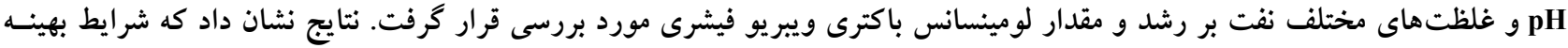

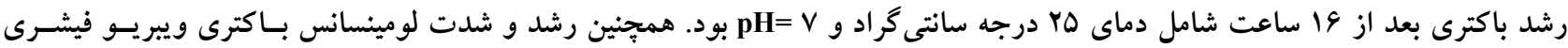

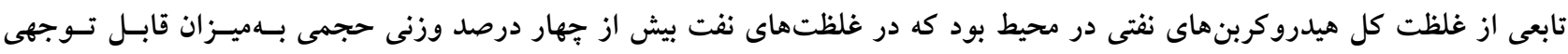

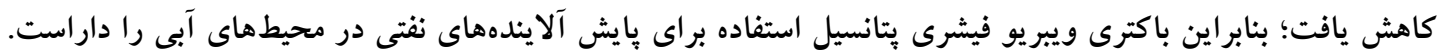

وازههاى كليدى: ويبريو فيشرى، پايش زيستى، باكترىهاى بيولومينسنت، آلايندهاى نفتى، آلودگى آب 


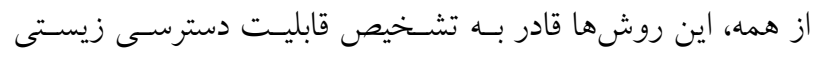

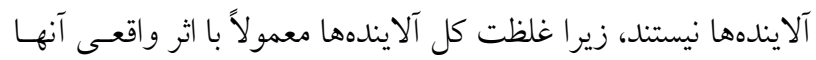

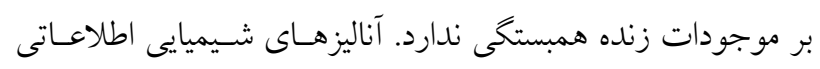

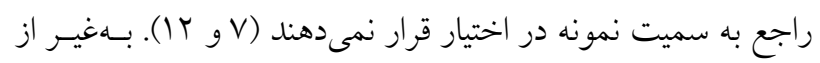

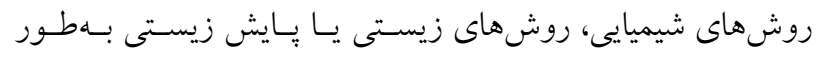

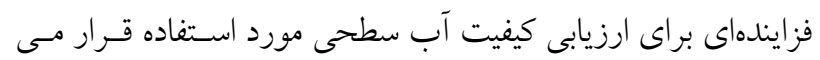

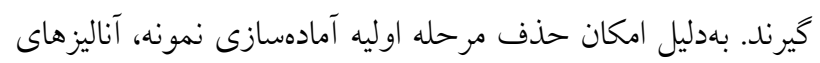

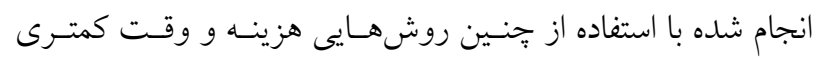
مصرف مى كنند. هدف از بايش زيستى ارزيـابى وضعيت محسيط

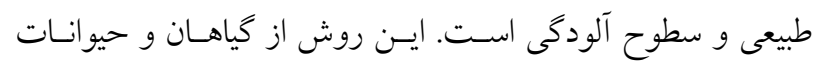

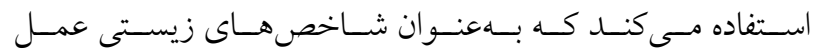

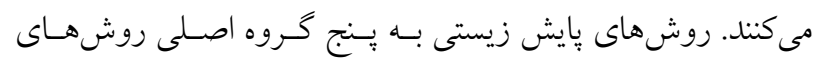

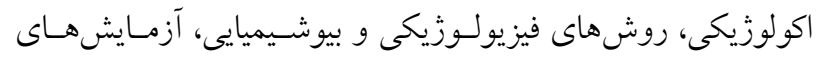

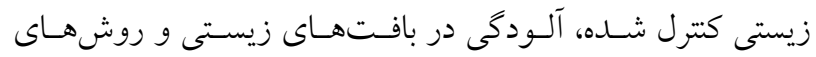

بافتشناسى و ريختشناسى تقسيم مىشوند (YY).

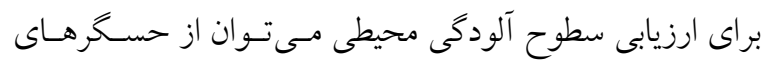

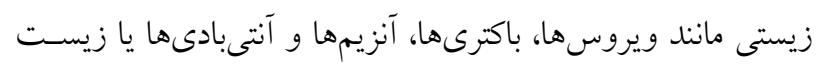

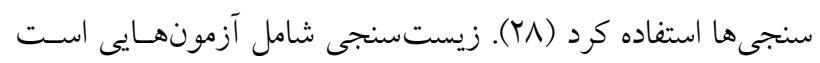

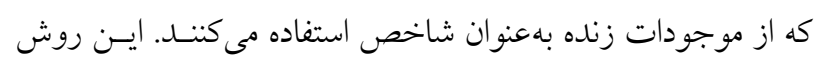

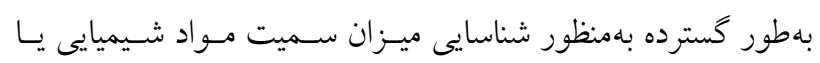

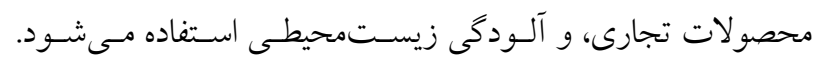

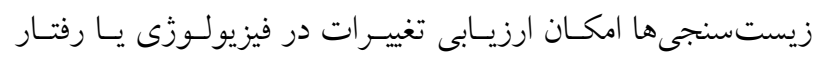

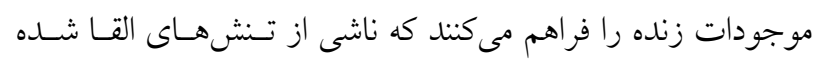

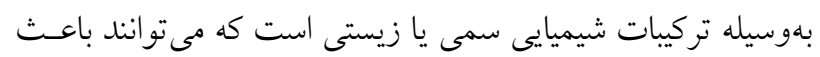

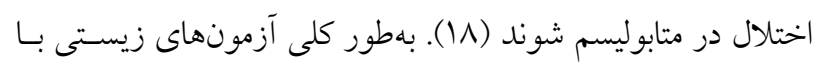

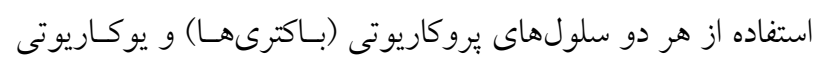

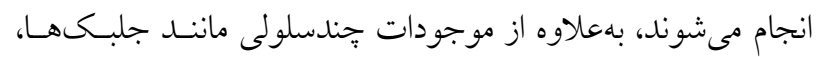

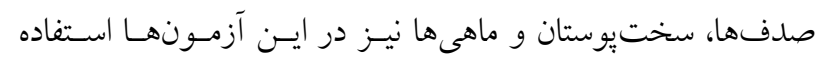

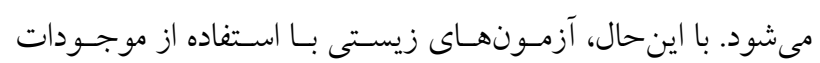
جندسلولى هزينهاى بالا و دورههاى توليد مثلى طولانى نيـاز دارد.

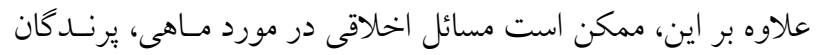

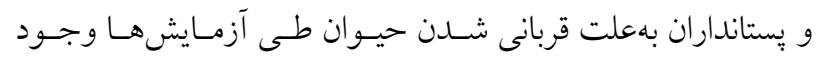

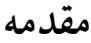

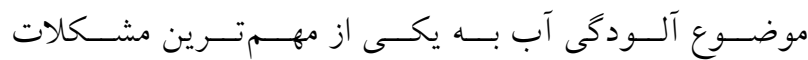

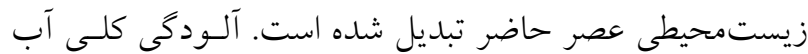

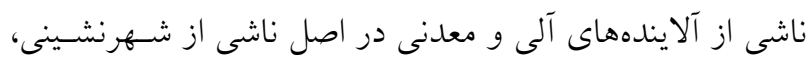

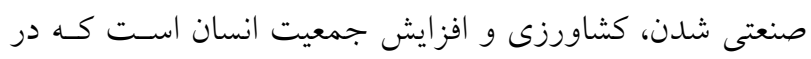

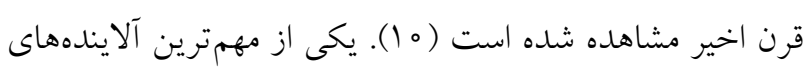

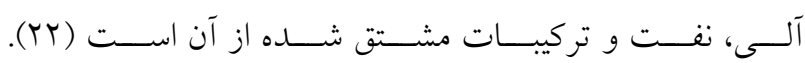

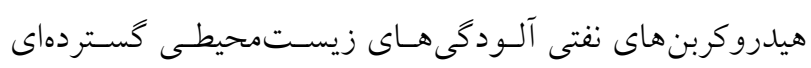

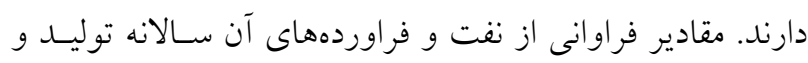

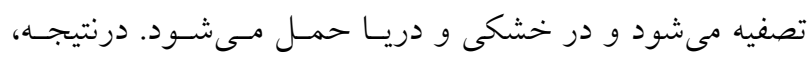

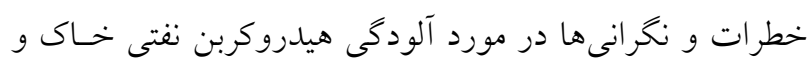

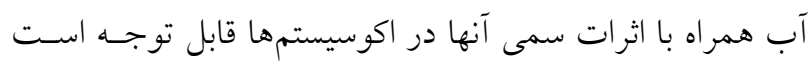

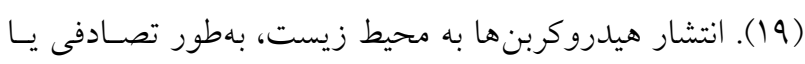

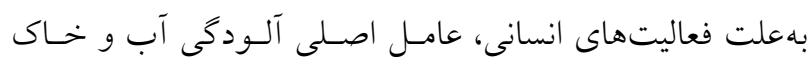

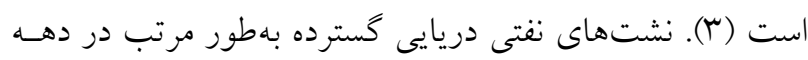

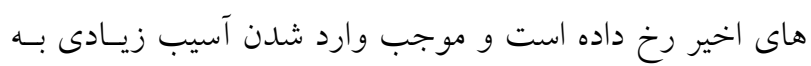

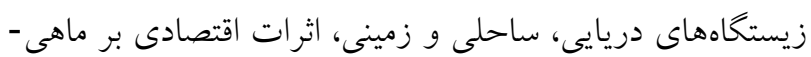

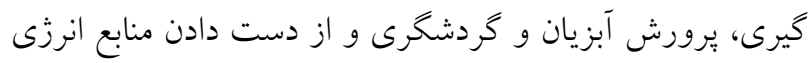
شده است. تراوش نفت از طريق خطوط لولـه، يالايشـاههـا و

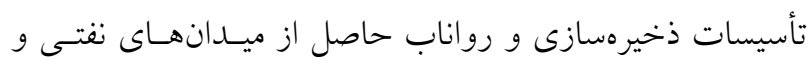

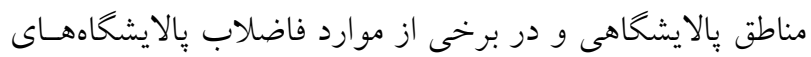

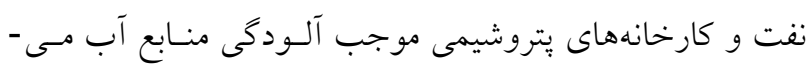

شود (19).

آلودكى محيطهاى طبيعى يك مشكل جهانى است كه سـلامتى (1).

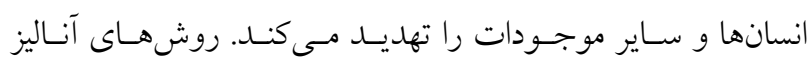

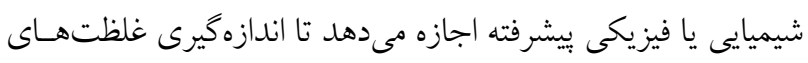

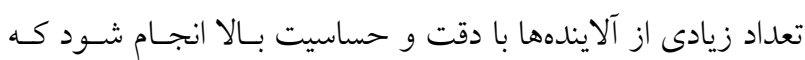

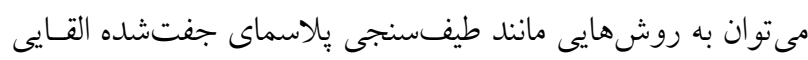

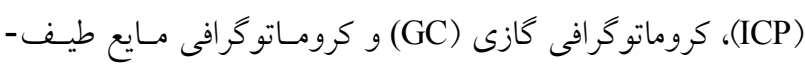

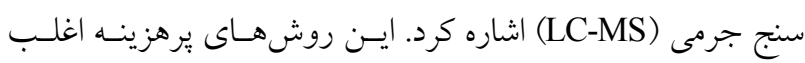

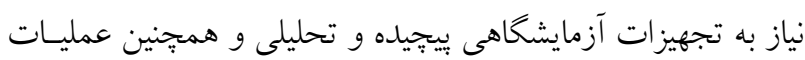

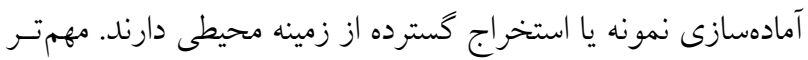


شناسى در زمينه نفت خـام روى قسـمت قابـل حـل در آب تأكيـد

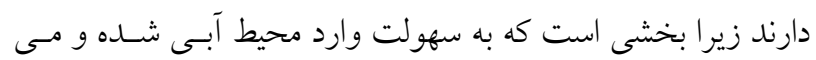

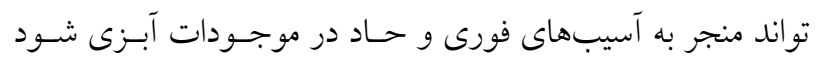

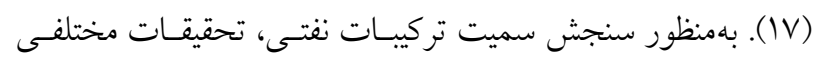

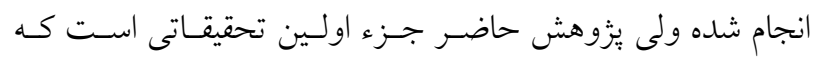

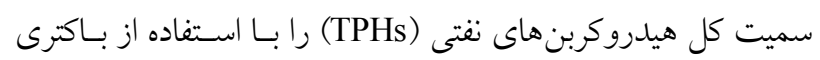

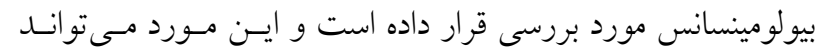

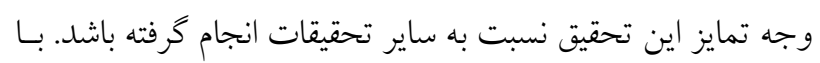

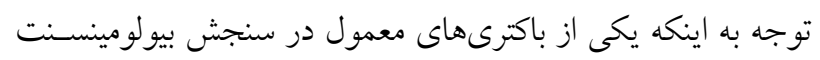

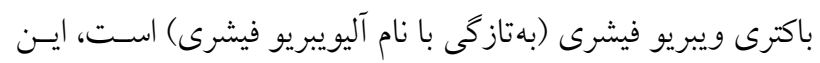

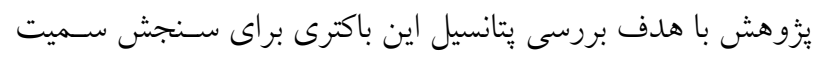

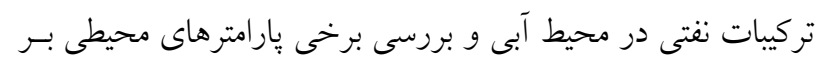
رشد و نورافشانى باكترى مورد بررسى قرار كرفته است.

\section{مواد و روشها \\ تهيه و كشت باكترى}

ويبريو فيشرى يكى باكترى گرم منفى، ميلهاى شكل، تـازكدار و و

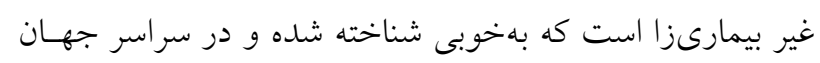

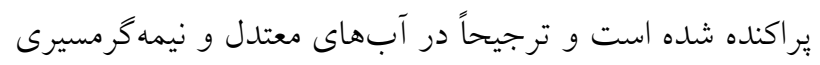

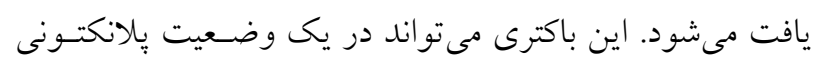

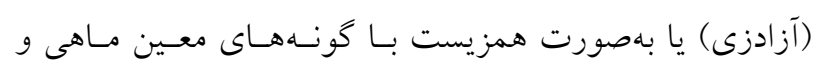

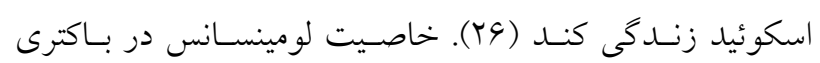

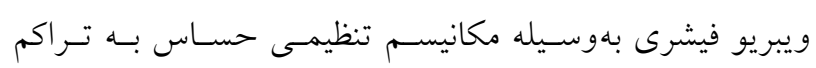

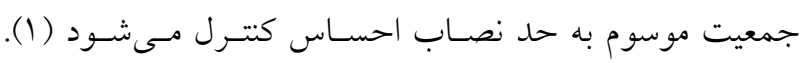

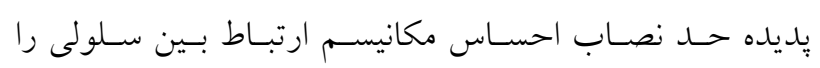

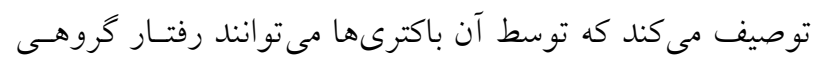

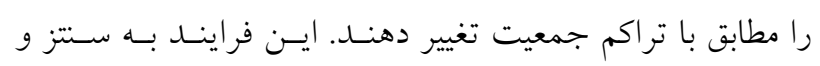

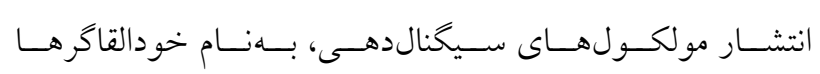

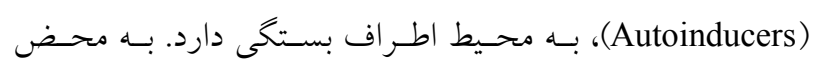

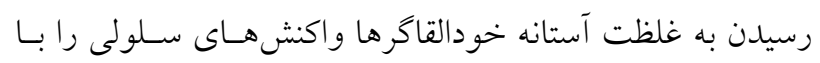

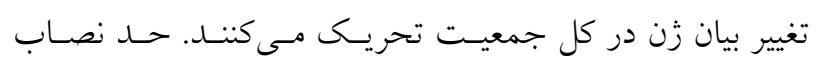
احساس، طيف گستردهاى از فرايندها در باكترىها شامل توليـد نديد
داثته باشد. بنابراين، آزمونهاى زيسـتى بــا اسـتفاده از سـلولهـاى

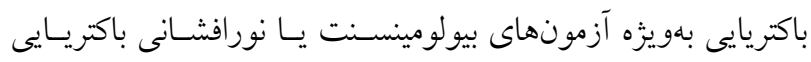

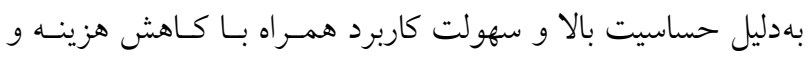

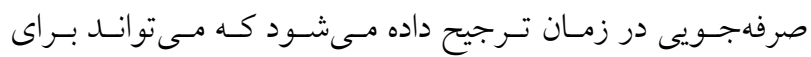

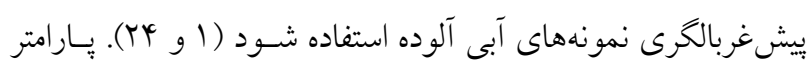

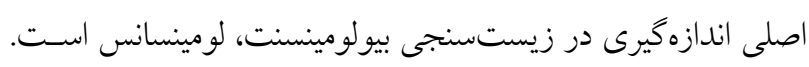

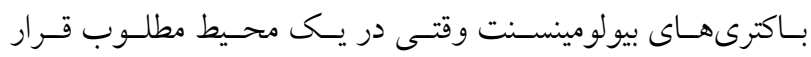

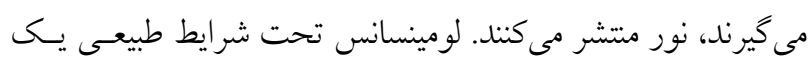

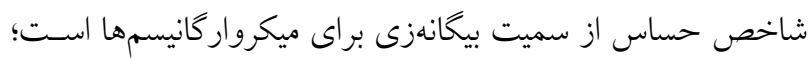

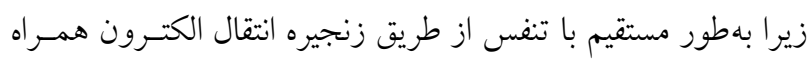

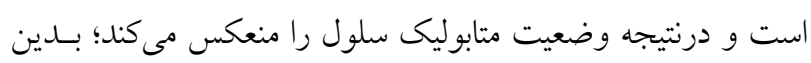

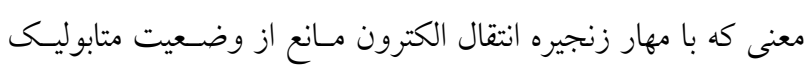

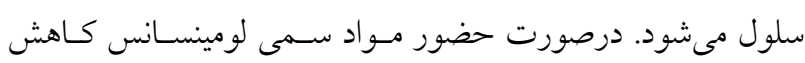

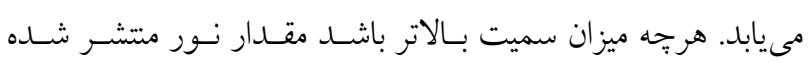
توسط باكترىها كمتر مىشود (A).

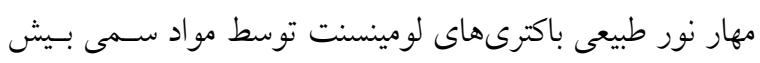

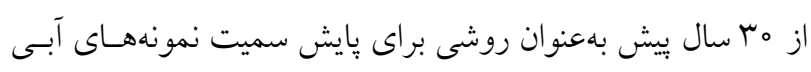

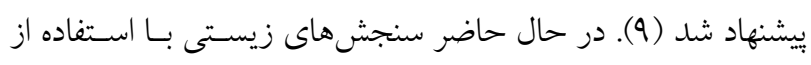

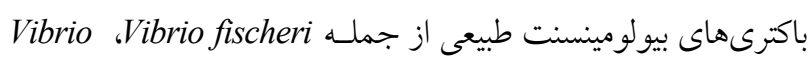
Pseudomonas gseudomonas fluorescens harveyi leiognathi بهور كسترده در آزمونهاى سميت بــكـار مسىرونـــ

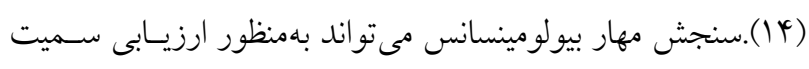

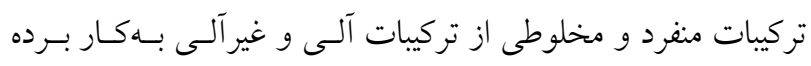

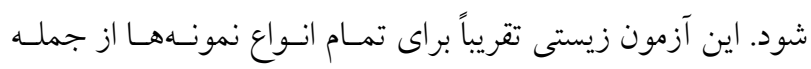

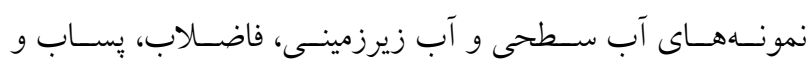

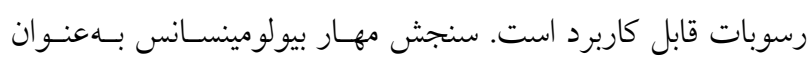

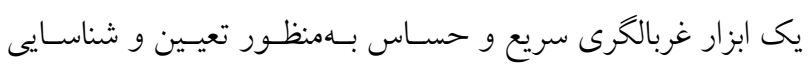

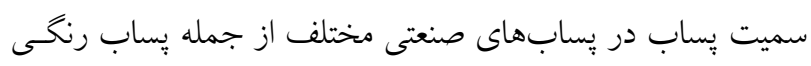

صنعت نساجى و كارخانه كاغذسازى استفاده شده است (Y) (Y).

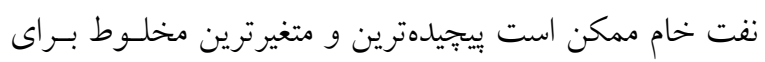

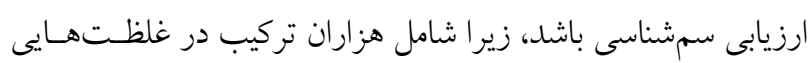

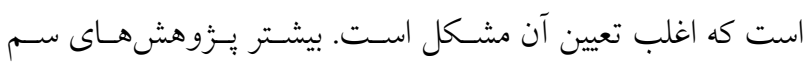


نورى در طول موج 900 نانومتر بلوسيله دستكاه اسبكتروفتومتر اندازهخيرى شد. (Jasco v-530)

\section{اثر عوامل محيطى بر رشد باكترى ويبريو فيشرى}

اثر اثر

محيط كشت فتوباكتريوم براث در جهار مقـدار مختلـف pH از

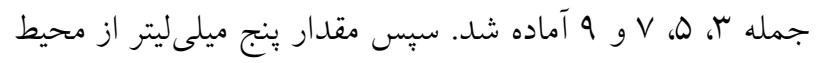
كشت به درون لولههاى آزمايش منتقل شد و بـاكترىهـا تلقـيح

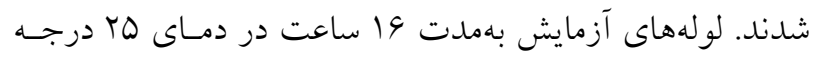

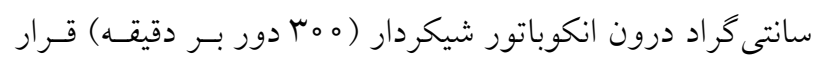

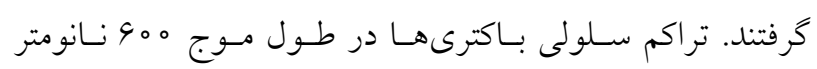

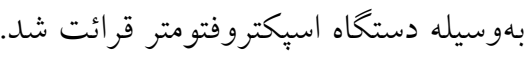

\section{اثر دما - - ماث}

محيط كشت فتوباكتريوم براث با pH نهايى حدود V كه قسـمت قبـل

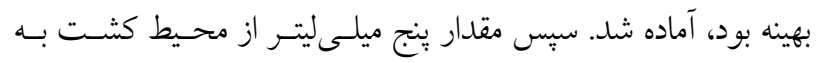

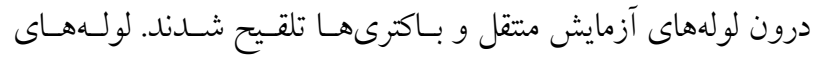

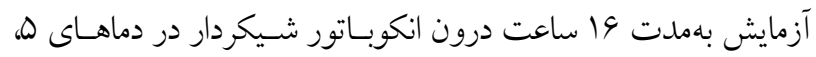

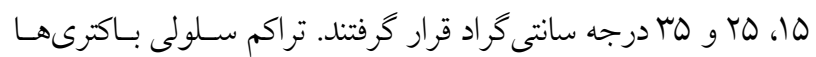

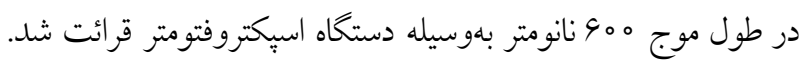

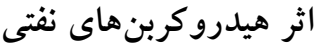

در يُزوهش حاضر بهمنظور بررسى سـنجش سـميت تركيبـات

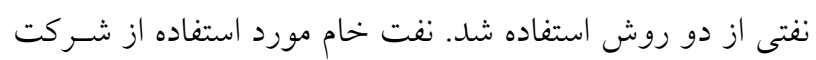
ويالايش نفت اصفهان تهيه شد.

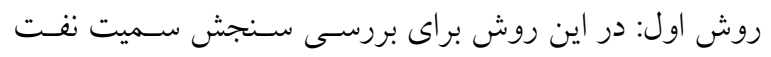

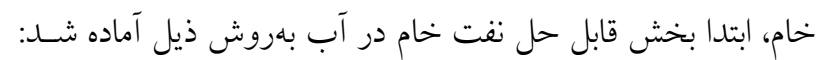

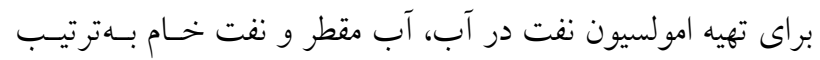

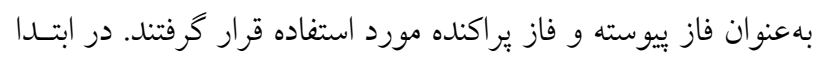

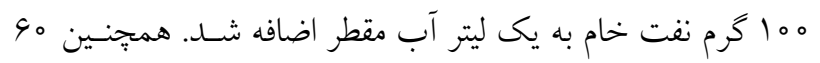

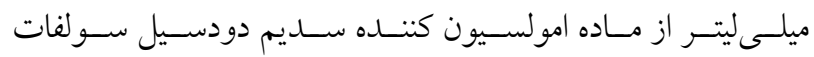
(Cا غلظت / / كرم بر ليتر به مواد قبلى (درحسالى $\left(\mathrm{C}_{12} \mathrm{H}_{25} \mathrm{NaO}_{4} \mathrm{~S}\right)$
بيولومينسانس، اسيورزايى، تشكيل بيوفيلم و سنتز آنتىبيوتيكها

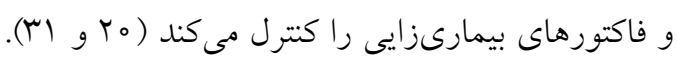

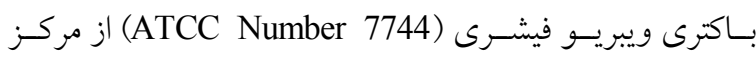

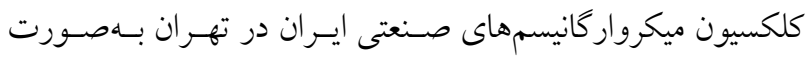

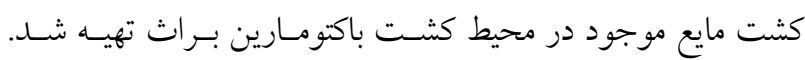

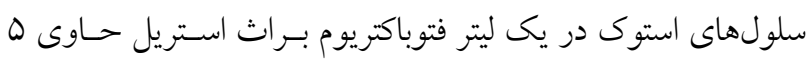

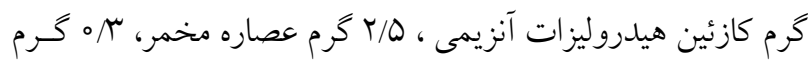

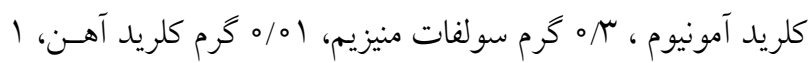

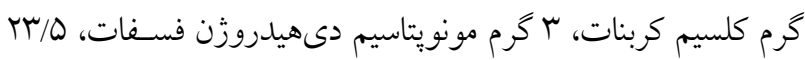

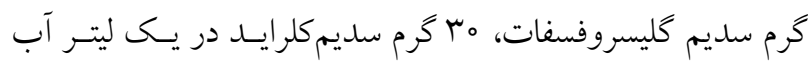

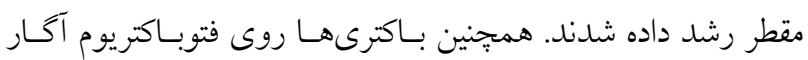

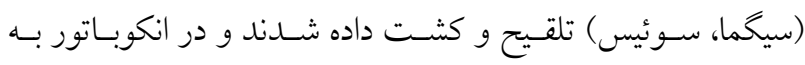

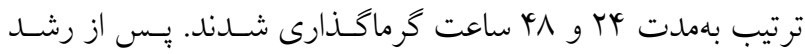

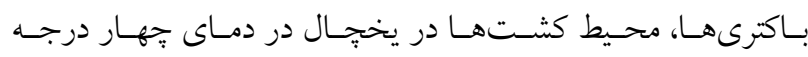

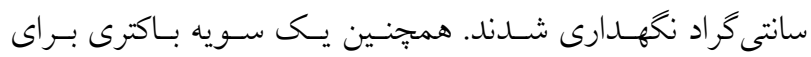

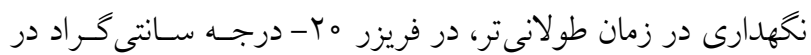

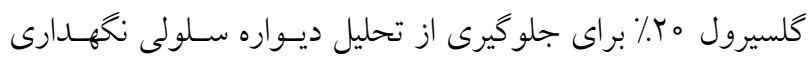

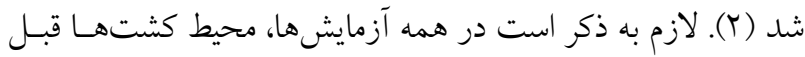

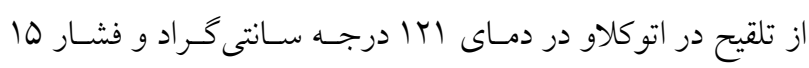
يوند بر اينج مربع بهمدت ها دقيقه استريل شدند.

\section{بررسى الخوى رشد باكترى ويبريو فيشرى}

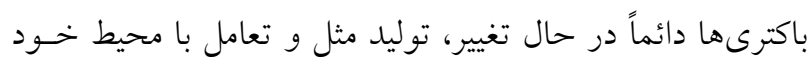

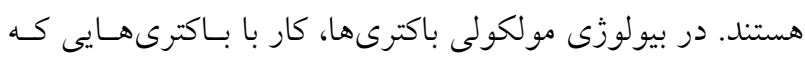

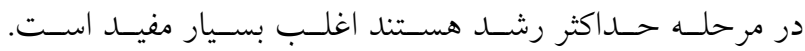

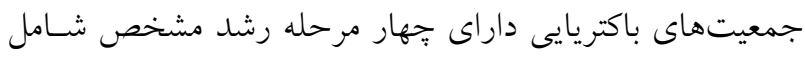
فاز تاخير، فاز نمايى، فاز سكون و فاز مرگ هستند. هـر مرحلـه.

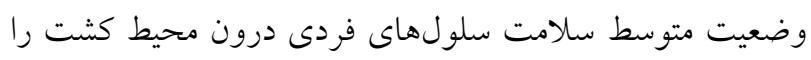

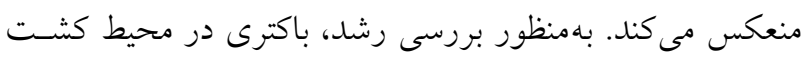

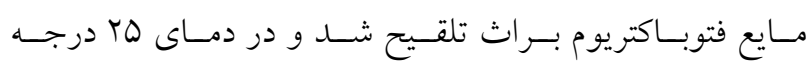

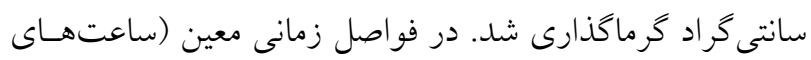

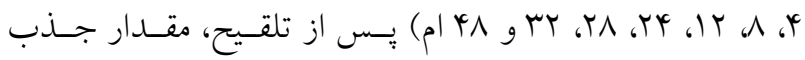




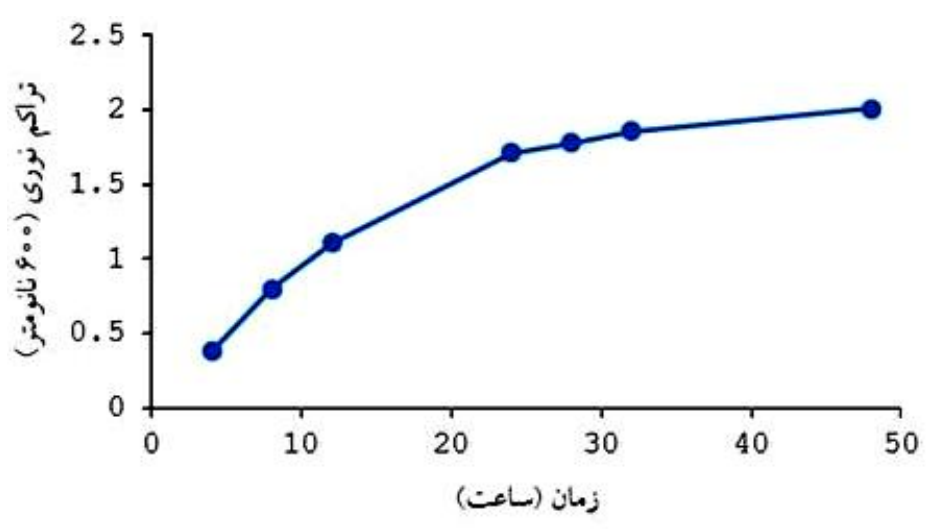

شكل ا. منحنى رشد باكترى ويبريو فيشرى در زمانهاى مختلف زمان

بهملت 9 اساعت، لايه نقتى به دقت جدا شد و ادامه مراحـل طبـق روش اول صورت گرفت. در اين روش براى بررسى لومينسـانس در دستخاه PMT، بهمنظور مقايسه همزمان دو تيمـار شـاهد (تيمـار باكترى بلدون حضور نفت در محسيط) و تيمـار حساوى نفـت، ابتـدا

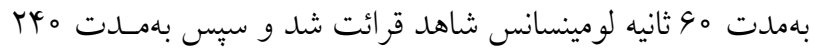
ثانيه تيمار غلظت نفت مورد بررسى، اندازهيرى شد. براى بررسى اختلاف ميانخين ميان غلظتهاى مورد بررسسى از آزمون مقايسه ميانخين Fisher's LSD در سطح اطمينان ه9 درصـد با بهرهگيرى از نرمافزار SPSS V.22 استفاده شد.

\section{نتايج و بحث

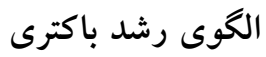

رشد ويبريو فيشرى بهعنوان تابعى از زمان تعيين شد. يكى نـوع رشـــ نمايى با كذشت زمان در منحنى رشد باكترى مشاهده مىشود (شـكل (). در ساعتهاى اوليه پِ از تلقيح، رشد سرعت جنــانى نداشـت. در ساعتهاى Y ا تا با باكترى در مرحله رشد نمايى قـرار داشـت و سبس به مرحله سكون نزديك شد. ساعت 19 ام كه حدوداً نيمه فـاز رشد لكاريتمى بود بهعنوان زمان بهينه رشد باكترى درنظر كرفتـه شـد كه بويايى باكترى حفظ شود و به فاز سكون نرسيده باشد.

اثر عوامل محيطى بر رشد باكترى اثر pH و دما شرايط بهينه براى رشد ويبريو فيشرى قبـل از سـنجش سـميت
كه روى لرزاننده مغناطيسى هم دور بر دقيقه قرار داشـت)، اضـافه

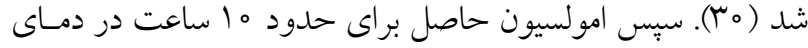
Tr درجه سانتى گراد داخل تانك سونيكاتور قرار گرفت. بـس از آن بهمدت يك ساعت امولسيون در حالت سـكون قــرار گرفـت تـا از جداسازى نفت يراكنده نشده در آب اطمينان حاصل شـود. بـس از عبور دادن محلول ساخته شده از كاغذ صافى واتمن بَأ، امولسـيون حاصل از فيلتر ميكروبى ه\&/ه ميكرومتر نيز عبور داده شد (T/).

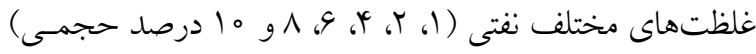
در نسبتهاى مختلف محلـول نفـت و محسيط كشـت فتوبـاكتريوم براث تهيه شد. سبس باكترى ويبريو فيشرى درون محلولهاى تهيـهـ

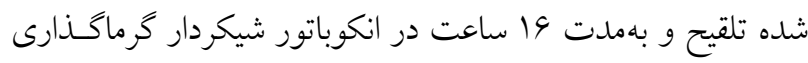

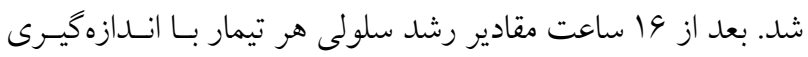
تراكم نورى بهوسيله دستخاه استيكتروفتومتر قرائت شـد. بـس از آن

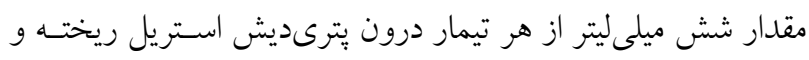

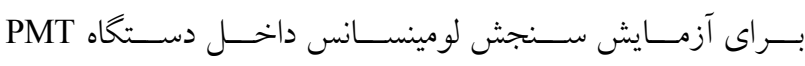
(Hamamatsu R6094) با واحد تعداد فوتون بر ثانيه در مدت مهب ثانيه اندازهگيرى شد. روش دوم: نقت خام بـهـهـورت يـك لايسه نفتى روى ميـزان مشخصى از محيط كشت استريل شده ( ا ميلىليتر) داخـل تيـوب

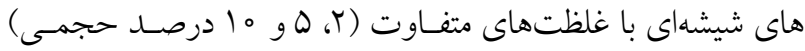
ريخته شد. سبِ بهميزان نفت ريخته شده، سديم دودسيل سولفات (T، هو م ا درصد حجمى) بهعنوان سورفكتانت نيز بهمنظـور حـل كردن بخش قابل حل نفت خــام اضـافه شـــ بعـــ از گرماكـذارى 


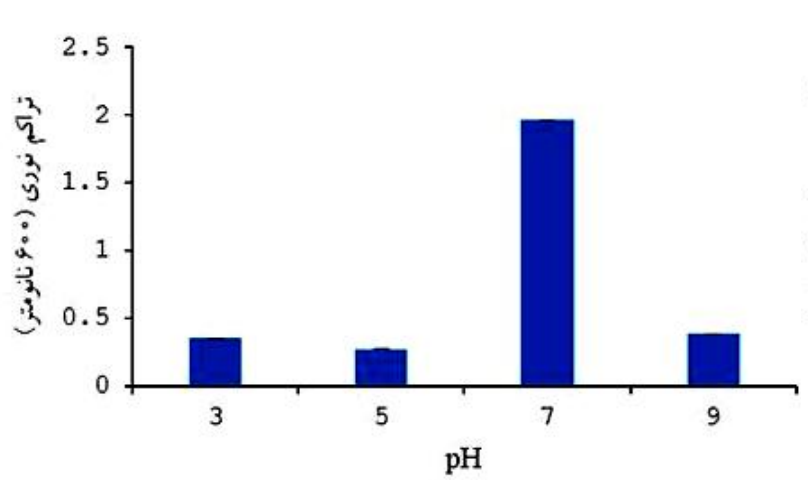

شكل r. اثر دما بر رشد باكترى ويبريو فيشرى (دادهها نمايانكر ميانگين نتايج \ انحر اف معيار هستند).

Lماى حدود مب درجسه سـانتى گ ادراد در محسيط كشـت LBS كزارش شده است (YV) - (Y).

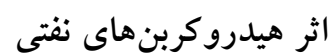

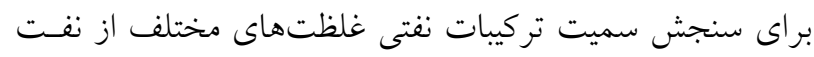

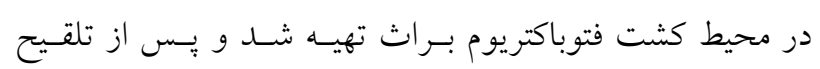

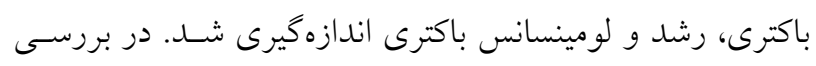

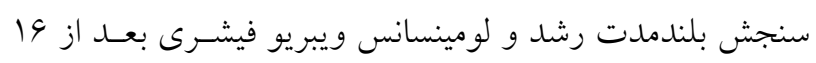

$$
\text { ساعت اندازه خيرى شد. }
$$

نتايج روش اول اختلاط نفت با محيط كشت نشـان داد كـه أنس

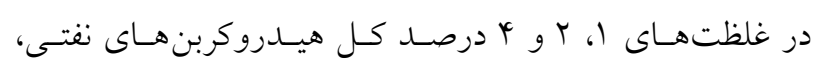

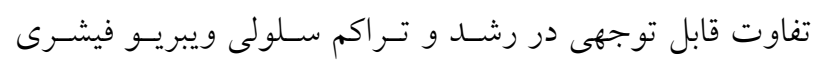

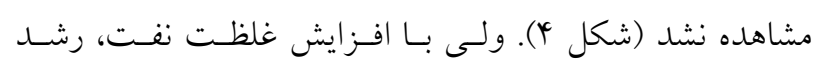

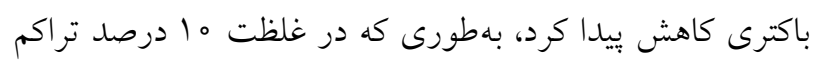

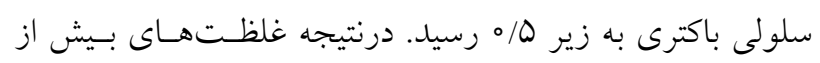

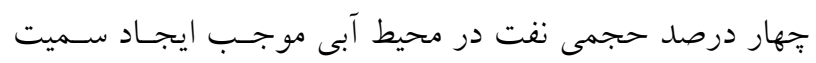

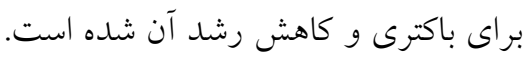

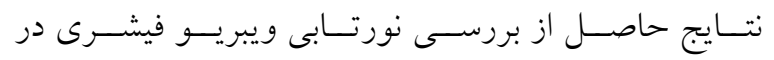

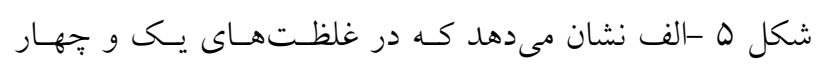

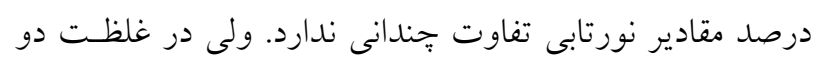

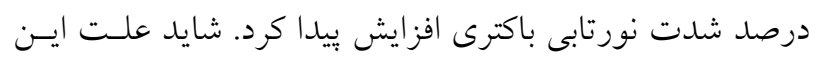

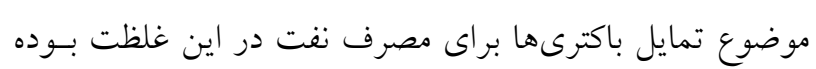

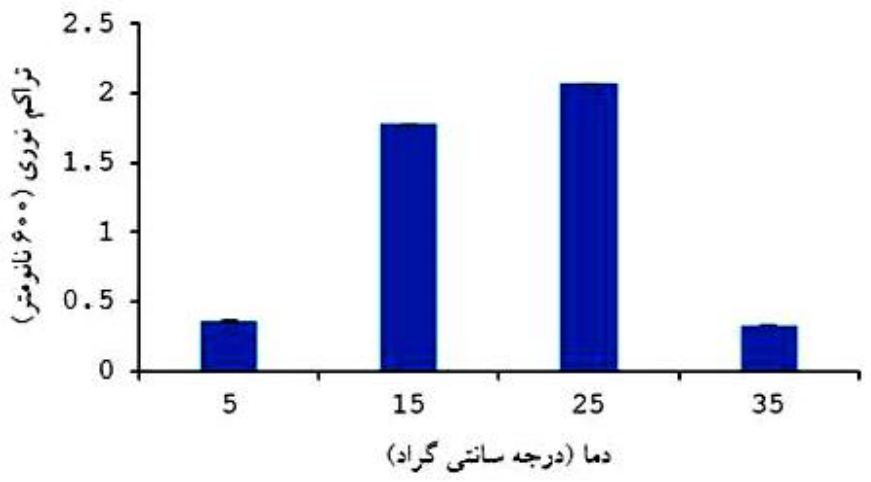

شكل r. اثر pH بر رشد باكترى ويبر يو فيشرى (دادهها نمايانكر ميانخين نتايج 土ـ انحر اف معيار هستند).

تعيين شد. در تمام هH باكترى ويبريو فيشرى قـادر بـه رشـــ

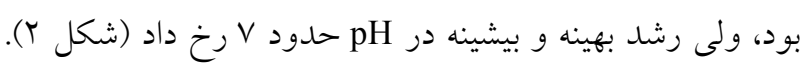

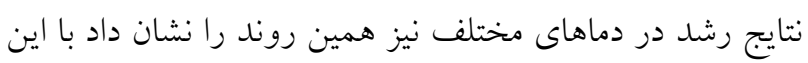

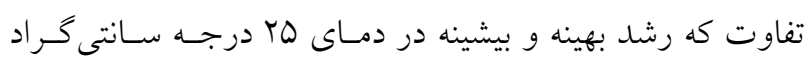

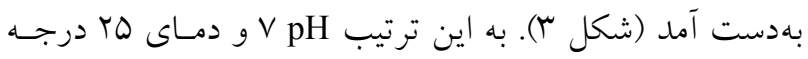

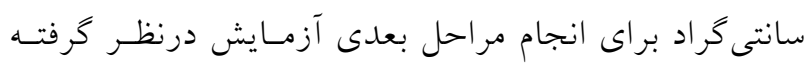

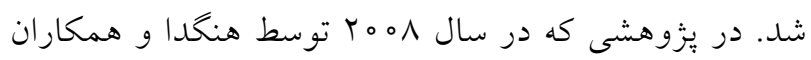

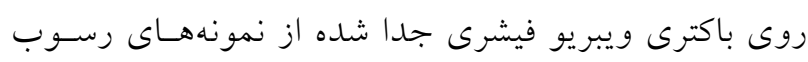

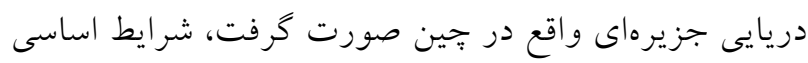

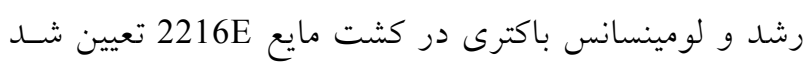

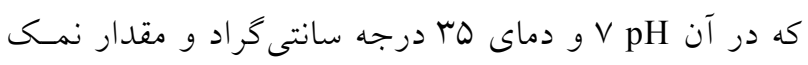

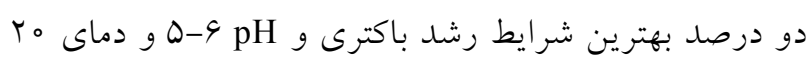

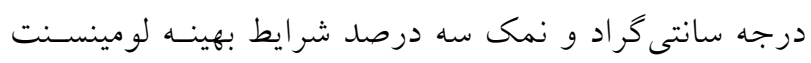

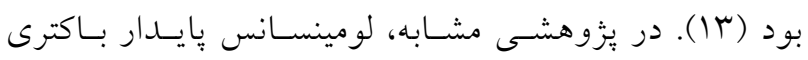
Photobacterium phosphoreum دماى ها درجه سانتى گراد و مقدار نمك Y/Q/ه درصد مشاهده

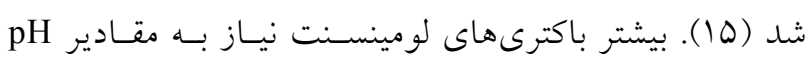

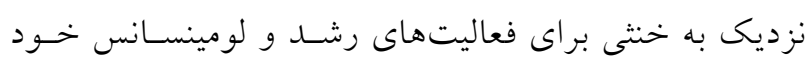

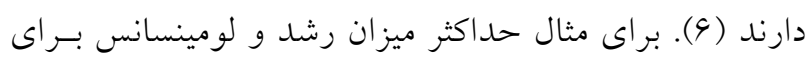

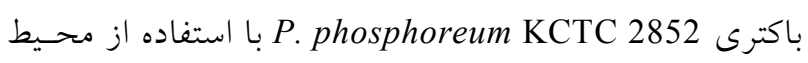

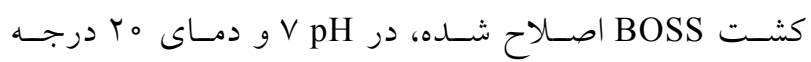
سانتى گراد (1) و براى باكترى ويبريو فيشرى در V/O pH و 


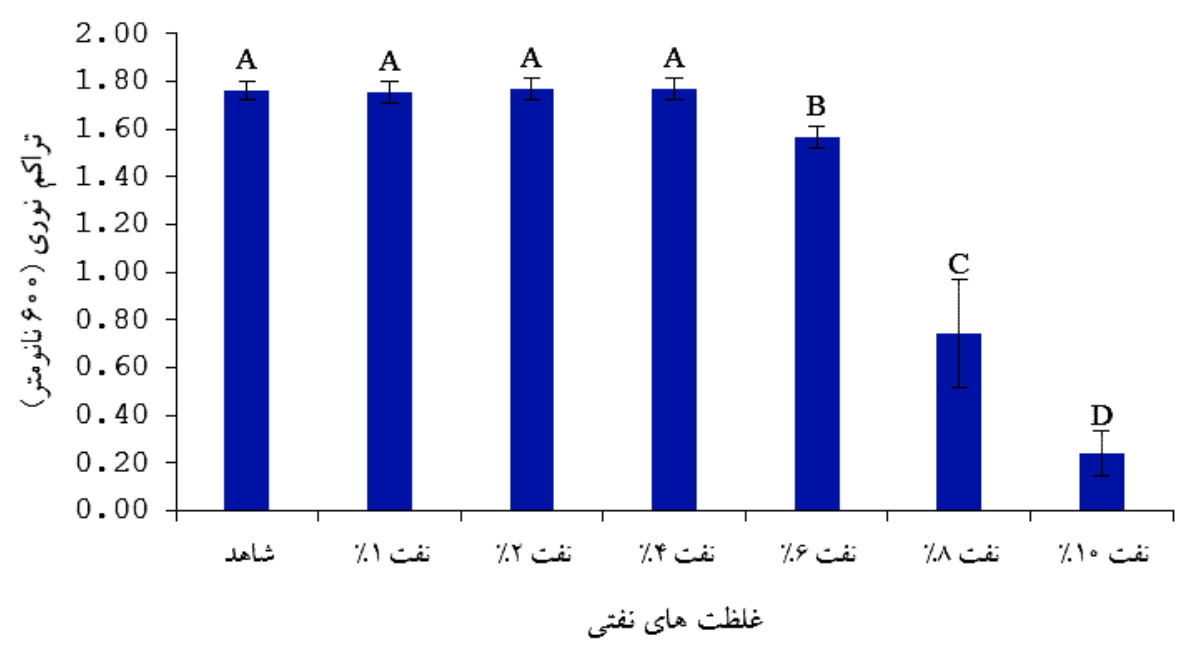

شكل f. اثر غلظتهاى مختلف نفت خام محلول در محيط كثت (اختلاط داده شده) بر رشد باكترى ويبريو فيشرى. دادهها نمايانكر ميانگين نتايج

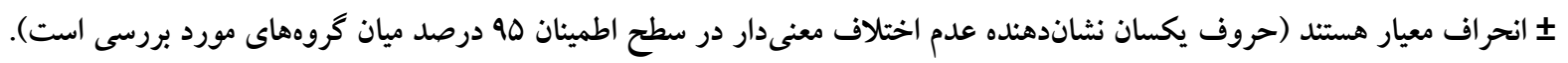
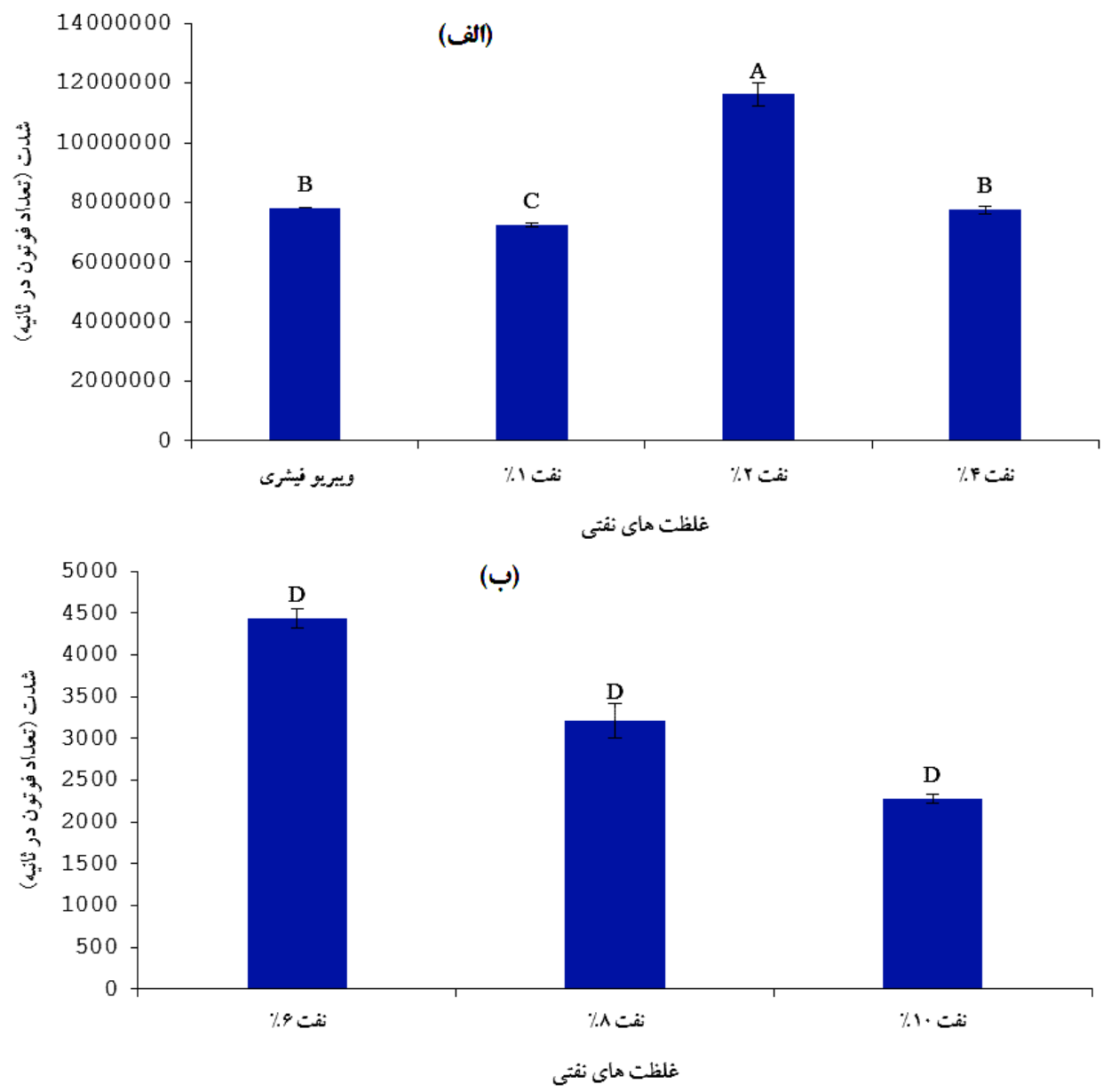

شكل ه. اثر غلظتهاى مختلف نفت اضافه شده روى محيط كثت بهصورت ستونى: الف) غلظتهاى ا، ب و F درصد حجمى و ب) غلظتهاى

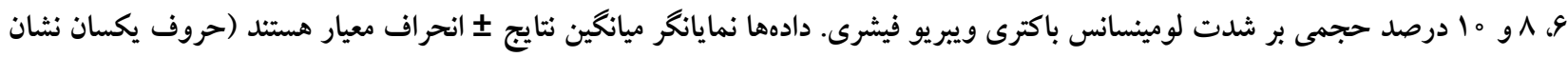

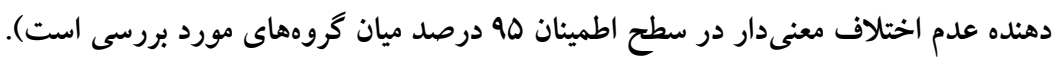




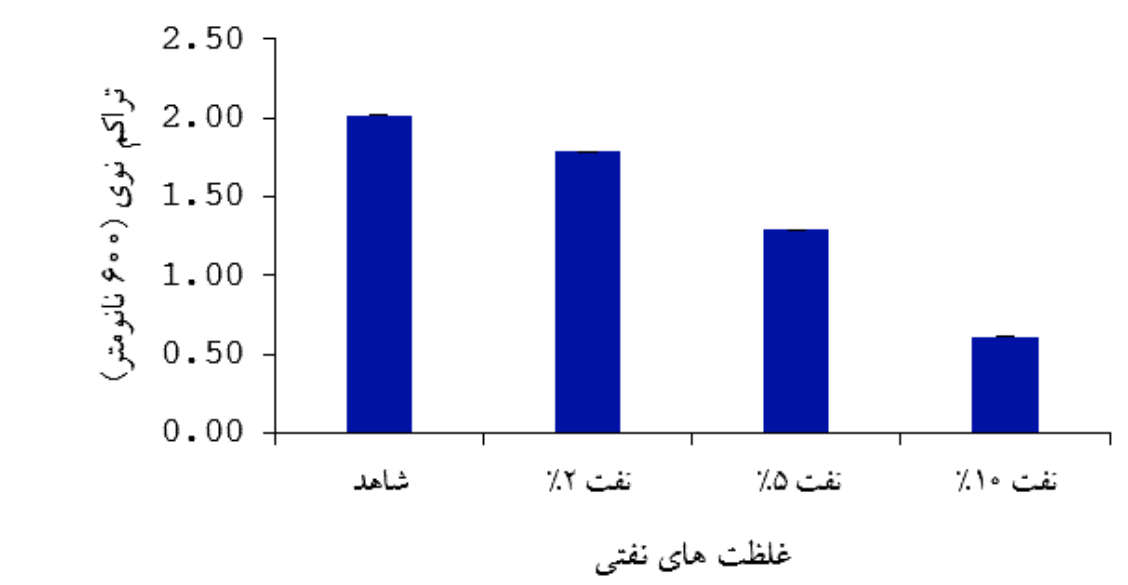

شكل 9. اثر غلظتهاى مختلف نفت در محيط كشت بهصورت ستونى بر رشد باكترى ويبريو فيشرى

(دادها نمايانغر ميانگين نتايج ـ انحر اف معيار هستند).

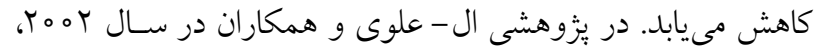

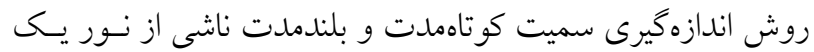

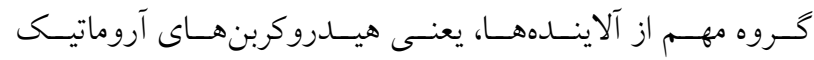

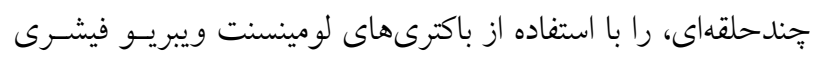

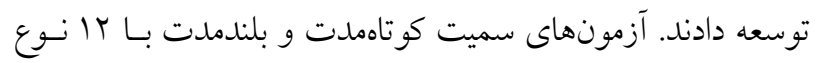
تركيب آروماتيك حلقوى مختلف انجام شد. سـنجش كوتـاهمــات

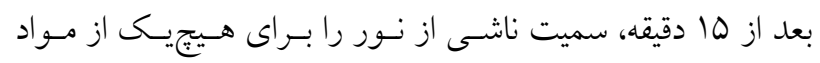

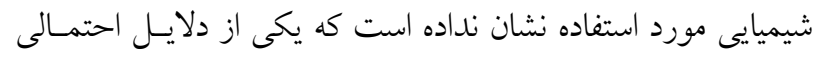

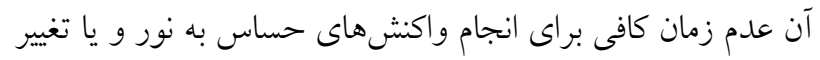

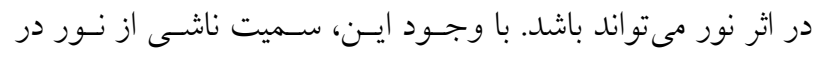

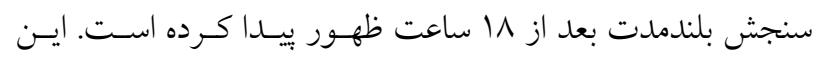

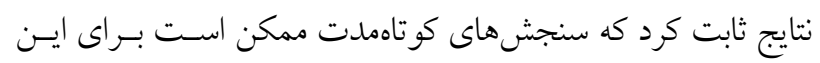
مكانيسم كليدى سميت تركيبات آروماتيك حلقوى مبهم باشد (†) (†).

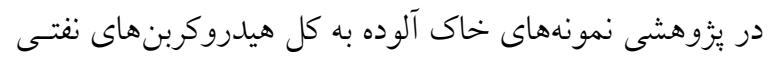

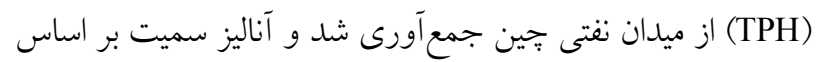

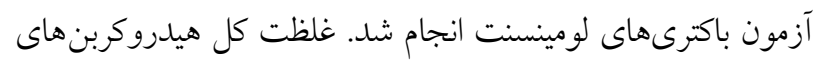

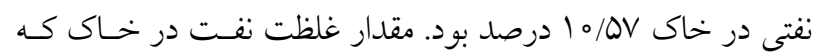

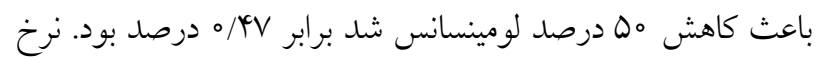

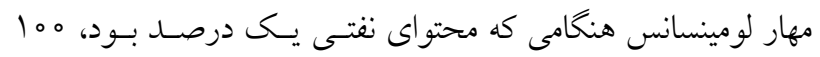

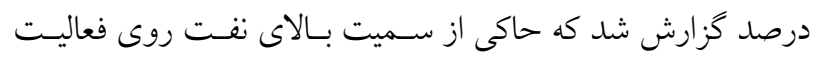

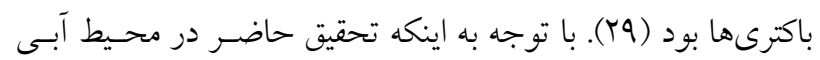

است و با افزايش غلظت ميزان هيـدروكربن موجـود در محيط بيش از نياز مصرفى باكترى بـوده اسـت. بــراى اطمينـان از ايسن

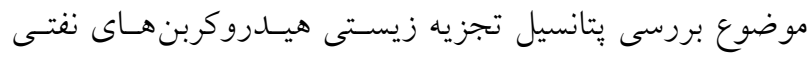

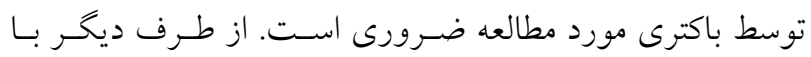

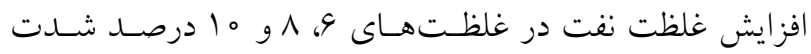
لومينسانس كاهش شـديدى داشـت (شـكل ه- ب) كـه بيـانكر سميت تركيبات نفتى براى باكترى مورد مطالعه است و با نتـايج رشد باكترى نيز همخوانى نشان مى دهد.

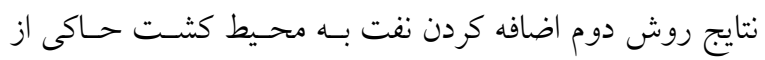

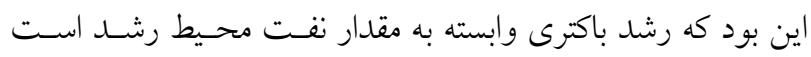

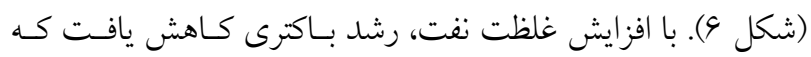

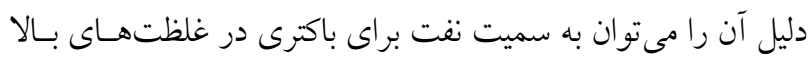

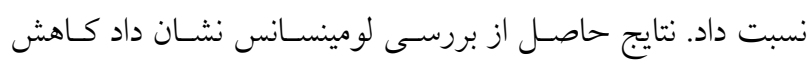

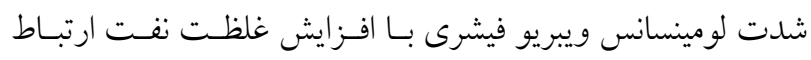

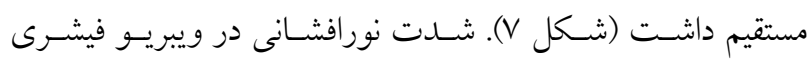

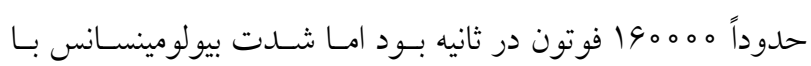
افزايش غلظت نفت كـاهش جشـمخيرى داشـته بـهـورى كـه در غلظت ه ا درصد نفت به حدود صفر رسيد. اين كـاهش جشـمخير

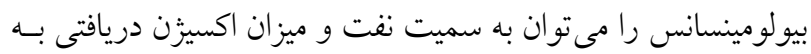
باكترى نسبت داد. با افـزايش ضـخامت لايسه نفتى ميـزان اكسيزن كمترى به باكترى رسيده و درنتيجه رشد و بهتبع آن لومينسانس نيـز مئز 
(الفف)

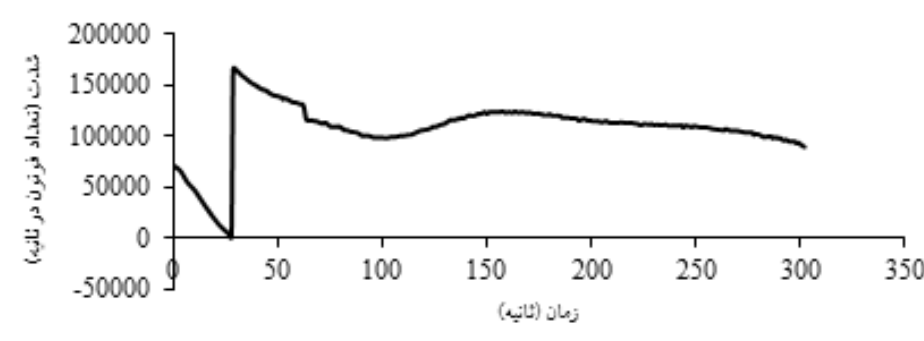

(ب)

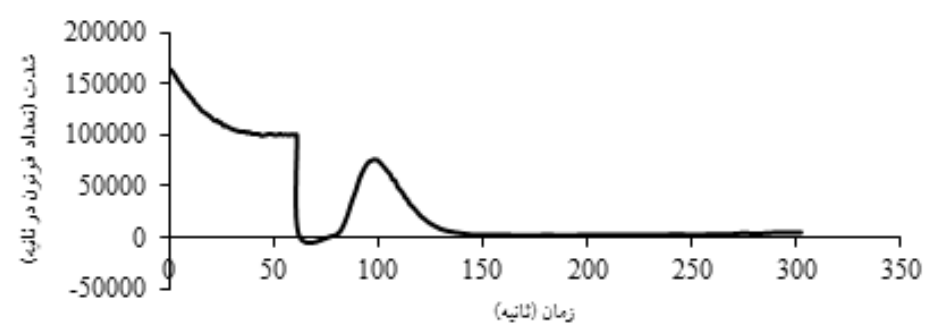

$(?)$

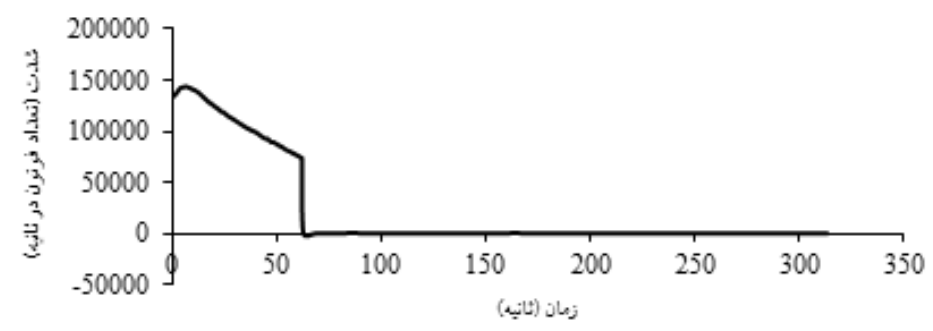

شكل V. تاثير غلظتهاى مختلف نفت در محيط كثت بهصورت ستونى (الف: Y درصد ، ج: 1 درصد) بر شدت لومينسانس باكترى ويبريو فيشرى

دوره زندكى دافنيا مخنا و غلظت نفت خام فقط در غلظتهاى بـالا ارتباط معنى دار وجود داشت و در غلظتهــاى بـايين نقـت ارتبـاط معنى دار مشاهده نشد (TO). بنـابراين بـهنظـر مسىرســ حساسـيت روش استفاده از باكترى در اين تحقيـق مشـابه نتـايج تحقيـق كفتـه شده در غلظتهاى كم نقت، بايين است.

\section{نتيجه كيرى}

پايش زيستى با استغاده از باكترىهاى بيولومينسنت در سالهاى اخير بيش از بيش مورد توجسه قــرار گرفتـه و بـهـدليـل مزايـاى فراوان از جمله بـه حـــاقل رسـاندن زمـان شناسـايى، افـزايش
انجام شد، امكان مقايسه نتايج با محيط خاكى كـه قبلال اشـاره شـد وجود نداشت و متأسفانه در بررسى منــابع مـوردى كـهـ در آن اثـر

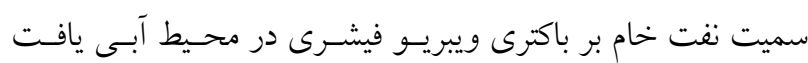
نشد. با وجود ايسن نتـايج يـروهش بيـانخر بتانسـيل بـالاى بـاكترى ويبريو فيشرى در محيط حاوى نفت با غلظتهاى بـالاتر (بـيش از جهار درصد حجمى نفت خام) بود. يكى از روشهاى رايج مـورد اسـتفاده بـراى سـنجش سـميت تركيبات نفتى استفاده از دافنيا مخنا است. بهعنوان مثال مطالعهاى كـه رئ

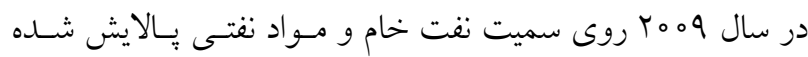

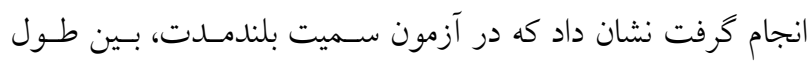




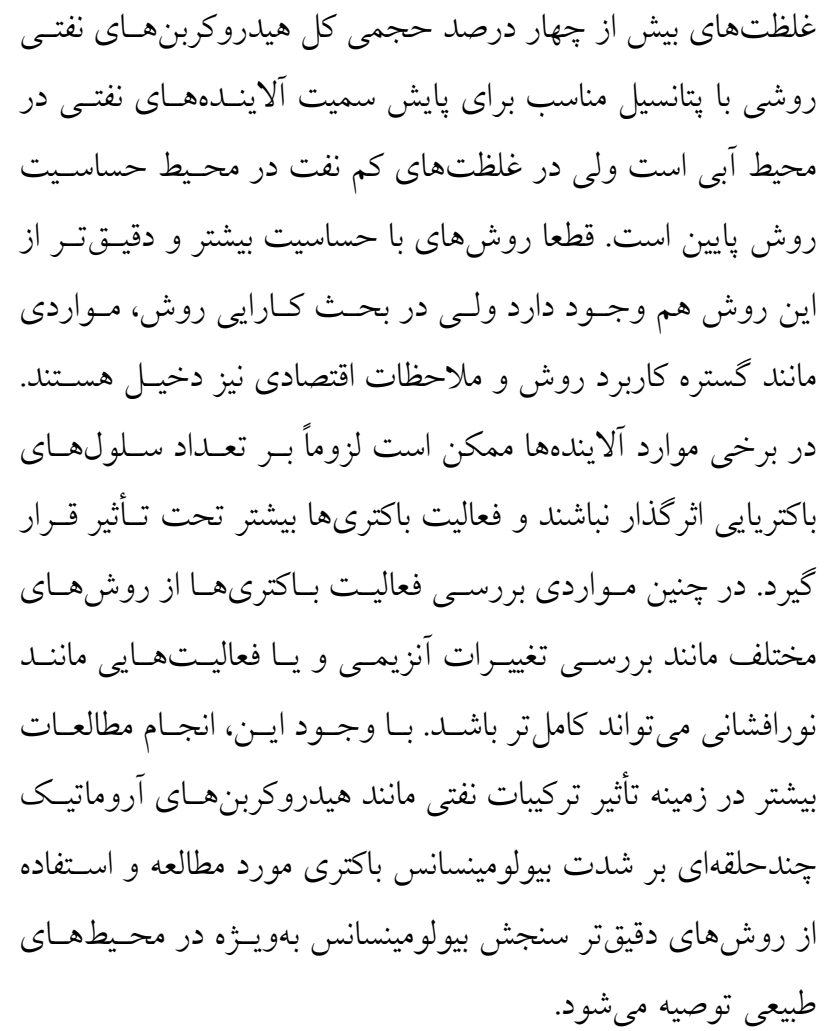

1. Abbas, M., M. Adil, S. Ehtisham-ul-Haque, B. Munir, M. Yameen, A. Ghaffar, G. A. Shar, M. A. Tahir and M. Iqbal. 2018. Vibrio fischeri bioluminescence inhibition assay for ecotoxicity assessment: A review. Science of the Total Environment 626: 1295-1309.

2. Budsberg, K., C. Wimpee and J. Braddock. 2003. Isolation and identification of Photobacterium phosphoreum from an unexpected niche: migrating salmon. Applied and Environmental Microbiology 69(11): 6938-6942.

3. Das, N. and P. Chandran. 2011. Microbial degradation of petroleum hydrocarbon contaminants: an overview. Biotechnology Research International 2011: 1-13.

4. El-Alawi, Y. S., B. J. McConkey, D. G. Dixon and B. M. Greenberg. 2002. Measurement of short-and long-term toxicity of polycyclic aromatic hydrocarbons using luminescent bacteria. Ecotoxicology and Environmental Safety 51(1): 12-21.

5. Ellis, R. and A. Wright. 1999. Optimal use of photomultipliers for chemiluminescence and bioluminescence applications. Luminescence 14(1): 11-18.

6. Farmer, J. J. and F. W. Hickman-Brenner. 2006. The genera vibrio and photobacterium. PP. 508-563. In: Dworkin, M., S. Falkow, E. Rosenberg, K. Schleifer and E. Stackebrandt, (Eds.), The Prokaryotes. Vol. 6. Springer, New York, NY.

7. Fernández-Piñas, F., I. Rodea-Palomares, F. Leganés, M. González-Pleiter and M. A. Muñoz-Martín. 2014. Evaluation of the ecotoxicity of pollutants with bioluminescent microorganisms. PP. 65-135. In: Thouand, G. and R. Marks (Eds.), Bioluminescence: Fundamentals and Applications in Biotechnology-Volume 2. Advances in Biochemical Engineering/Biotechnology, Vol 145. Springer, Berlin, Heidelberg.

8. Girotti, S., L. Bolelli, A. Roda, G. Gentilomi and M. Musiani. 2002. Improved detection of toxic chemicals using bioluminescent bacteria. Analytica Chimica Acta 471(1): 113-120.

9. Girotti, S.; Ferri, E. N.; Fumo, M. G. \& Maiolini, E. 2008. Monitoring of environmental pollutants by bioluminescent bacteria. Analytica Chimica Acta 608(1): 2-29.

10. Goel, P. 2006. Water Pollution: Causes, Effects and Control. 2nd Edition. New Age International.

11. Hassan, S. H. and S. E. Oh. 2010. Improved detection of toxic chemicals by Photobacterium phosphoreum using modified Boss medium. Journal of Photochemistry and Photobiology B: Biology 101(1): 16-21. 
12. Hassan, S. H., S. W. Van Ginkel, M. A. Hussein, R. Abskharon and S. -E. Oh. 2016. Toxicity assessment using different bioassays and microbial biosensors. Environment International 92-93: 106-118.

13. Hongda, F., D. Yanhong, X. Zhanzhou, Y. Yin, L. Xiuqin and Y. Bin. 2008. Cultural and luminescent conditions of a marine luminous bacterium. Marine Science Bulletin 10(1): 1-8.

14. Kudryasheva, N., V. Kratasyuk, E. Esimbekova, E. Vetrova, E. Nemtseva and I. Kudinova. 1998. Development of bioluminescent bioindicators for analysis of environmental pollution. Field Analytical Chemistry \& Technology 2(5): 277-280.

15. Kuts, V. and A. Ismailov. 2009. Physiological and emission characteristics of the luminescent bacterium Photobacterium phosphoreum from the White Sea. Microbiology 78(5): 612-617.

16. Lim, T. -T. and X. Huang. 2007. Evaluation of kapok (Ceiba pentandra (L.) Gaertn.) as a natural hollow hydrophobic-oleophilic fibrous sorbent for oil spill cleanup. Chemosphere 66(5): 955-963.

17. Martinez-Jeronimo, F., R. Villasenor, G. Rios and F. Espinosa-Chavez. 2005. Toxicity of the crude oil water-soluble fraction and kaolin-adsorbed crude oil on Daphnia magna (Crustacea: Anomopoda). Archives of Environmental Contamination and Toxicology 48(4): 444-449.

18. Medvedeva, S. E., N. A. Tyulkova, A. M. Kuznetsov and E. K. Rodicheva. 2009. Bioluminescent bioassays based on luminous bacteria. Journal of Siberian Federal University 2: 418-452.

19. Megharaj, M., I. Singleton, N. McClure and R. Naidu. 2000. Influence of petroleum hydrocarbon contamination on microalgae and microbial activities in a long-term contaminated soil. Archives of Environmental Contamination and Toxicology 38(4): 439-445.

20. Molina, A., R. Tuazon and L. Larman. 2015. Responses of Bioluminescent Bacteria Isolated from Philippine Marine Fishes to Various Heavy Metals. Australian Journal of Basic and Applied Sciences 9(13): 38-42.

21. Parvez, S., C. Venkataraman and S. Mukherji. 2006. A review on advantages of implementing luminescence inhibition test (Vibrio fischeri) for acute toxicity prediction of chemicals. Environment International 32(2): $265-268$.

22. Potters, G. 2013. Marine Pollution. Bookboon.

23. Rajak, V., S. Kumar, N. Thombre and A. Mandal. 2018. Synthesis of activated charcoal from saw-dust and characterization for adsorptive separation of oil from oil-in-water emulsion. Chemical Engineering Communications 205(7): 897-913.

24. Ranjan, R., N. K. Rastogi and M. Thakur. 2012. Development of immobilized biophotonic beads consisting of Photobacterium leiognathi for the detection of heavy metals and pesticide. Journal of Hazardous Materials 225: 114-123.

25. Ratushnyak, A. A., M. G. Andreeva, V. Z. Latypova, R. R. Shagidullin and M. V. Trushin. 2009. Toxicity of oil and products of its refinement to Daphnia magna: time and temperature dependences. American-Eurasian Journal of Agricultural and Environmental Science 5(4): 545-549.

26. Scheerer, S., F. Gomez and D. Lloyd. 2006. Bioluminescence of Vibrio fischeri in continuous culture: Optimal conditions for stability and intensity of photoemission. Journal of Microbiological Methods 67(2): 321-329.

27. Soto, W., J. Gutierrez, M. Remmenga and M. K. Nishiguchi. 2009. Salinity and temperature effects on physiological responses of Vibrio fischeri from diverse ecological niches. Microbial Ecology 57(1): 140-150.

28. Szczerbiñska, N., and M. Gałczyñska. 2015. Biological methods used to assess surface water quality. Archives of Polish Fisheries 23(4): 185-196.

29. Tang, J., M. Wang, F. Wang, Q. Sun and Q. Zhou. 2011. Eco-toxicity of petroleum hydrocarbon contaminated soil. Journal of Environmental Sciences 23(5): 845-851.

30. Tony, M. A., P. J. Purcell, Y. Zhao, A. M. Tayeb and M. El-Sherbiny. 2009. Photo-catalytic degradation of an oilwater emulsion using the photo-fenton treatment process: effects and statistical optimization. Journal of Environmental Science and Health Part A 44(2): 179-187.

31. Verma, S. C. and T. Miyashiro. 2013. Quorum sensing in the squid-Vibrio symbiosis. International Journal of Molecular Sciences 14(8): 16386-16401. 


\title{
An Investigation of the Potential of Vibrio fischeri Bacterium for Monitoring of Oil Pollution in Aqueous Media
}

\author{
M. Mirjani ${ }^{1}$, M. Soleimani ${ }^{*}$ and V. Salari ${ }^{2}$
}

(Received: April 9-2019; Accepted: June 22-2019)

\begin{abstract}
Growing concerns about water pollution and its potentially harmful effects on human being have stimulated serious efforts to develop reliable biological monitoring techniques. The bioluminescent analysis is one of the most promising approaches for the biomonitoring of the environment, due to the sensitivity of the luminescent system to even micro quantities of the pollutants. The aim of the current study was to assess the petroleum compounds toxicity using Vibrio fischeri bacterium. The growth pattern of the bacterium was determined in photobacterium broth using the optical density measurement at $600 \mathrm{~nm}$, which showed the optimum growth time of 16-18 hours after inoculation. In this research, the effects of environmental parameters such as temperature, $\mathrm{pH}$ and various concentrations of oil on the growth and luminescence of Vibrio fischeri were examined. The results revealed that the optimum growth conditions of the bacterium after 16 hours included the temperature of $25^{\circ} \mathrm{C}$ and $\mathrm{pH} 7$. Besides, the growth and luminescence intensity of Vibrio fischeri were a function of total petroleum hydrocarbon concentrations in the medium, which were significantly reduced in oil concentrations by more than $4 \% \mathrm{w} / \mathrm{v}$. Therefore, the Vibrio fischeri could, have the potential for monitoring of petroleum pollutants in the aqueous media.
\end{abstract}

Keywords: Vibrio fischeri, Biomonitoring, Bioluminescent bacteria, Petroleum pollutants, Water pollution.

1- Department of Environmental Science, Faculty of Natural Resources, Isfahan University of Technology, Isfahan, Iran.

2- Faculty of Physics, Isfahan University of Technology, Isfahan, Iran.

*: Corresponding author, Email: m.soleimani@iut.ac.ir 